\title{
Study on the zooplankton of Sona Dighi in Rajshahi, Bangladesh
}

\author{
Sabrina Naz and Sirajun Najia \\ Department of Botany, University of Rajshahi, Rajshahi 6205, Bangladesh
}

\begin{abstract}
Zooplankton populations of Sona Dighi were remarkable. In all 31 genera and 45 species represented by five major groups have been reported from Sona Dighi, Rajshahi based on a year investigation. The recorded groups were as follows as Protozoa (5 genera, 4 species), Rotifera (7 genera, 11 species), Cladocera (6 genera, 8 species), Ostracoda (4 genera, 6 species) and Copepoda (9 genera, 15 species).Physical chemical characteristics and zooplankton diversity of the reservoir indicates its eutrophic nature.
\end{abstract}

Key words: Zooplankton,Sona Dighi,Rajshahi,Bangladesh.

\section{Introduction}

In freshwater system zooplanktons form an important group as most of them feed upon and incorporate the primary producers into their bodies and make themselves available to higher organisms in food chain (Michael, 1968). They play a major role in the energy transfer at secondary level. They contribute significantly to biological productivity of freshwater ecosystem. Thus they can be used as bio-indicators. In most of the aquatic ecosystem different zooplankton groups acts as one of the major primary consumer as a result their diversity, abundance and seasonality effects the other biotic components therein. The present communication deals with systematic description of zooplankton population of the reservoir named Sonadighi. During the study major limnological conditions were also taken under consideration.

\section{Materials and Methods}

Sona Dighi is situated in the central region of Rajshahi city. It is more or less rectangular in shape. The reservoir has a water span of $3633 \mathrm{~m}^{2}$ with a depth varying from $3.66 \mathrm{~m}$ to $4.88 \mathrm{~m}$ at mid region. Almost in all the sides brick- build embankment were present about 1 meter high from the water surface. There was no macro vegetation in the littoral zone and surface area of the reservoir. Monthly sampling was carried out for a year, three representative samples were collected from three selected sites of the water body. Samples were collected from below the surface using plankton net No: 20 silk bolting cloth (mesh size $0.076 \mathrm{~mm}$ ) and preserved in Transeau's solution (Transeau , 1951). The figures of individual zooplankter were drawn by camera lucida at the time of microscopic examination. Zooplankton were identified up to species level by following relevant literatures.

Water samples were collected on the same day from $20 \mathrm{~cm}$ below the surface to estimate the physical chemical condition of reservoir. The water samples were treated for physical chemical studies with the help of digital thermometer for temperature, Seccchi disk for transparency, with graduated rope with weight in one end for depth, digital $\mathrm{pH}$ meter (HANNA)for $\mathrm{pH}$, free carbon di oxide $\left(\mathrm{CO}_{2}\right)$, carbonate, bicarbonate $\left(\mathrm{HCO}_{3}\right)$, dissolved oxygen (DO), biochemical oxygen demand, chemical oxygen demand (COD), nitrate nitrogen
$\left(\mathrm{NO}_{3}-\mathrm{N}\right)$, calcium $(\mathrm{Ca})$, magnesium $(\mathrm{Mg})$ content and total hardness $(\mathrm{T}-\mathrm{H})$ were determined following Ambast (1990), APHA (1975), Welch (1948), APHA (1975), Sharup et al. (1992), Mishra and Saksena (1992).Oxidation reduction index $\left(\mathrm{rH}_{2}\right)$,oxidation reduction potential (Eh) were determined following Gautam (1990).

\section{Results and Observations}

Yearly range of the physical chemical parameters of the water concerned during the collection period is presented on in Table-1.

Table 1. Yearly range of physical and chemical parameter

\begin{tabular}{l|l|l|l}
\hline \multicolumn{1}{c|}{ Parameter } & \multicolumn{1}{c|}{ Range } & \multicolumn{1}{c}{ Parameter } & \multicolumn{1}{c}{ Range } \\
\hline Air Temp & $21.5-30.5^{\circ} \mathrm{C}$ & Transparency & $14-42.54 \mathrm{~cm}$ \\
\hline Water Temp & $16-30.7^{\circ} \mathrm{C}$ & Depth & \\
\hline DO & $0.98-7.12 \mathrm{mg} / \mathrm{l}$ & BOD & $0.42-7.12 \mathrm{mg} / \mathrm{l}$ \\
\hline $\mathrm{COD}$ & $2.99-16.01 \mathrm{mg} / \mathrm{l}$ & $\mathrm{Eh}$ & $0.18-.48$ \\
\hline $\mathrm{pH}$ & $7.1-9.1$ & $\mathrm{CO}_{2}$ & $2.8-130 \mathrm{mg} / \mathrm{l}$ \\
\hline $\mathrm{EC}$ & $331.33-$ & $\mathrm{HCO}_{3}$ & $41-336 \mathrm{mg} / \mathrm{l}$ \\
& $1104.45 \mu \mathrm{S} / \mathrm{cm}$ & & \\
\hline $\mathrm{rH}$ & & $\mathrm{Mg}-\mathrm{H}$ & $3.44-38.75 \mathrm{mg} / \mathrm{l}$ \\
\hline $\mathrm{T}-\mathrm{H}$ & $24.42-30.61$ & $\mathrm{Ca}-\mathrm{H}$ & $21-128 \mathrm{mg} / \mathrm{l}$ \\
\hline
\end{tabular}

\section{Systematic Enumeration}

Detailed description of the collected zooplankton along with their camera lucida drawings (Pl.1 and 2) are presented in the following lines.

Phylum: Protozoa

Super class: Lobosa Class: Amoebaea

Family: Thecamoebidae

1. Astramoeba radiosa Ehrenberg1830 (Pl.1 Fig. $1 \mathrm{x}$ 100) Edmondson 1966, p.235, Fig. 9.6.

Length $96 \mu$.Body spherical shaped. Pseudopodus more or less rigid, not withdrawn and reforme rapidly. Spherical shaped single nucleus. A few large radiating pseudo pods present.

Phylum : Ciliophora Class: Oligohymenophorea Order: Peniculida

Family: Paramecidae

2. Paramecium trichium Stokes1885 (Pl.1, Fig.4 x 675)Edmondson 1966, p.276, Fig. 10 11(f).

Single celled ovate body. Cilia present. Two contractile vacuoles, 1 in front and the other in rear half of the cell. 


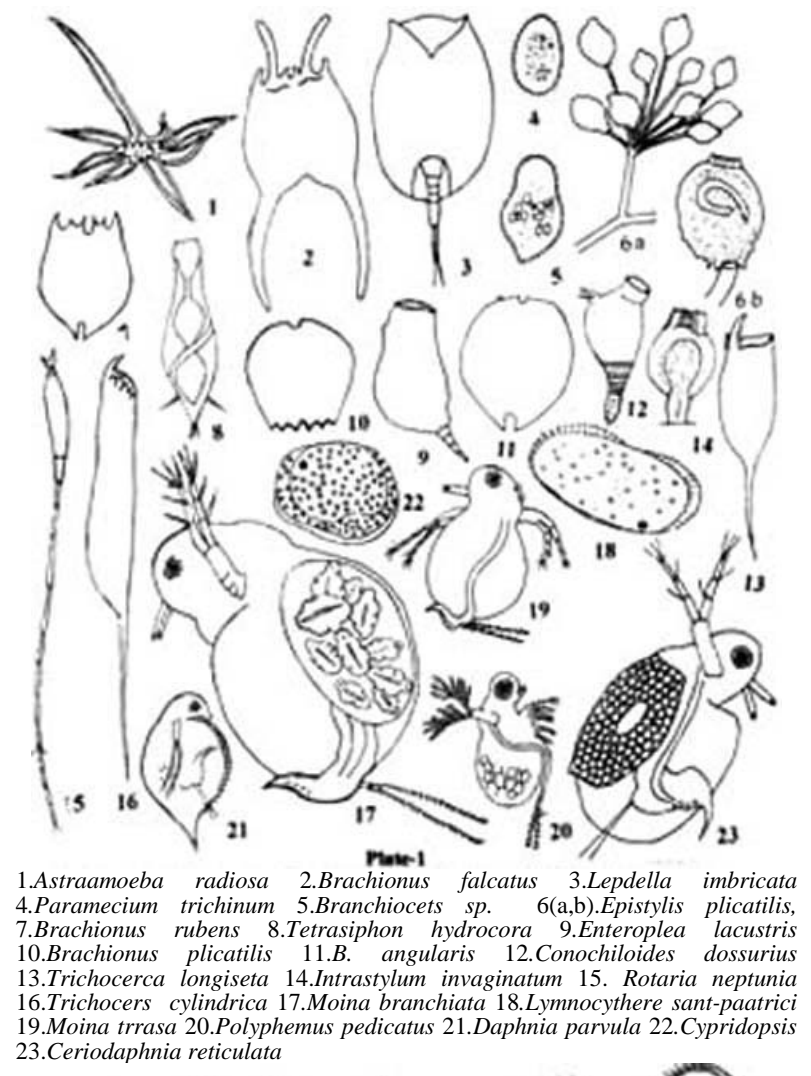

3.Ceriodaphnia reticulata

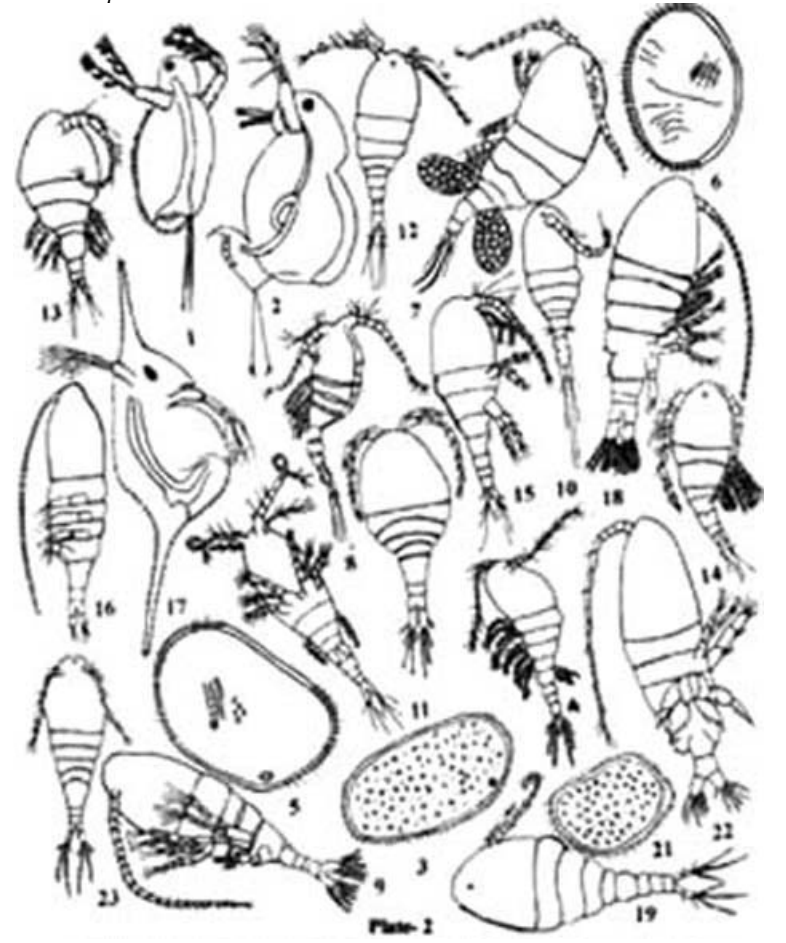

1.Diaphanosoma leuchtenbergianum 2.Drephanothrix dentata 3. Cypricercus horridus 4.Microcyclops sp. (female) 5.Cypricercus obliquus 6.Cyprois occidentalis 7.Cyclops varicans 8. Paracyclops fimbiatus poppei 9. Neodiaptomus strigilipes (male) 10. Cyclops nanus 11.Mesocyclops leukarii 12.Mesocyclops. dybowskii 13.Macrocyclops distinctatus 14.Mesocyclops inversus (female) 15. Mesocyclops hyalinus 16.Diptomus pygmaeus 17.Daphnia inversus (female) 15.Mesocyclops hyalinus 16.Diptomus pygmaeus 17.Daphnia
longispina 18.Heliodiptomus contortus 19.Cyclops vernalis 20.Cyclops bicolor 21Cypridopsis rhomboidea 22.Neodiaptomus strigilipes (female) 23.Eucyclops agilis.
Subphylum: Postciliodesmatophora Class: Litostomatea Order: Haptorida

Family:Tracheliidae

3. Branchioecetes sp. Kahl 1931(Pl.1, Fig.5 x 675) Edmondson 1966, p.273, Fig.1. 9(b).

Body unicellular and somewhat elliptical, flat, blade like in front view. Cilia present.

Class: Suctoria, Order: Chonotrichida

Family: Epistylidae

4. Epistylis plicatilis Ehrenberg1830 (Pl.1 Fig. 6a x100, 6b x 450) Edmondson 1966, p.292, Fig.10.30 (g).

Cilia present during free juvenile stages only, auctorial tentacles present. One individual at end of each branch of the colony stalk.

Family: Vorticellidae

5. Intranstylum invaginatum Stokes1886(Pl.1, Fig.14) Edmondson 1966, p.292, Fig.10.31 (a).

Spasmoneme poorly developed, stalk spiral. It was not found spiral when contracted. Cilia present on the auctorial tentacles when it was alive.

Phylum:Rotifera ,Class: Monogononta, Order: Ploima Family: Trichocercidae

6. Trichocerca longiseta Schrank, 1802 (Pl.1, Fig.13x600) Edmondson1966 p.448, Fig.18.22 (b).

Length of lorica $480 \mu$. Toes unequal. Breadth $243.1 \mu$.

7. Trichocerca cylindrica Imhof, 1891 (Pl.1, Fig.16 x 400) Edmondson 1966,p.448, Fig.18.22 (a)

Length of lorica $178 \mu$. Toes unequal. Breadth $148.5 \mu$. Lorica is cone shaped. Trophi virgule, asymmetric.

Family: Tetrasiphonidae

8. Tetrasiphon hydrocora Ehrenberg1840(Pl.1 Fig. $8 \mathrm{x}$ 100)Edmondson 1966,p.464, Fig.18.63 (a).

Long knobbed lateral antenna, near foot, two dorsal antennae are present. The virgule trophy highly modified. Somewhat spindle shaped. Four thickened mass like structure is looked in the body shell.

Family: Notommatidae

9. Enteroplea lacustris Ehrenberg1830,(Pl.1 Fig.9 x 100)Edmondson1966,p.467, Fig.18.73.

Length $626 \mu$, breadth mid region $208.67 \mu$ stomach with large band shaped, forked gastric glands and 2 pairs of other attached structures.

Family: Conochilidae

10. Conochiloides dossuarius Hudson 1885(Pl.1 Fig.12 x60) Bhouyain \& Asmat, 1992,p 172, Fig.162.

Body cup shaped, foot as long as body. Transparent jelly like substances covers foot and body end straight. Corona circular. Dorsal antennae small. Ordinarily solitary. Length $500 \mu$ and breadth in mid region $170 \mu$.

Family: Philodinidae

11. Rotaria neptunia Ehrenberg 1832 (Pl.1 Fig.15 x 100) Edmondson 1966, p.488, Fig.18.113(b). 
Corona two circular retractile lobes. Eye is present in probasis. Body length $1400 \mu$. It is known as the most elongate rotifer species.

Family: Brachionidae

Sub family: Brachioninae

12. Brachionus angularis Gosse, 1851 (Pl. 1, Fig. $11 \mathrm{x}$ 100) Edmondson, 1966,p 451, Fig.18.29(c).

Lorica more or less rounded. Anterior spines are narrow pointed and short with a short strethenning ridge. Median sinus prominent. Length $333 \mu$ and $233.1 \mu$ in diam.

13. Brachionus plicatilis Müller1786(Pl. 1, Fig.10 $\mathrm{x}$ 100) Edmondson, 1966,p 451, Fig.18.29(a).

Lorica more or less rounded. Foot annotated. 6 species present on the anterior pointed. Spines are short and ridges are not developed. Lorica length $315 \mu$ and $310 \mu$ in diam.

14. Brachionus rubens Ehrenberg, 1838(Pl. 1, Fig.7 $\mathrm{x}$ 100) Bhouyain \& Asmat, 1992,p 113, Fig. 80.

Lorica firm, divided into a dorsal and a ventral plate. Lorica moderately compressed dorso-ventrally. Anterior dorsal margin with two median spines divided by a U-shaped sinus. Lateral and median spines weakly developed. Lorica $340 \mu$ and $371 \mu$ in diam.

15. Brachionus falcatus Zacharias, 1898 (Pl. 1, Fig. 2 x 100) Bhouyain \& Asmat, 1992,p 107, Fig.80.

Lorica firm, divided into a dorsal and a ventral plate, quite compressed dorso-ventrally. Anterior dorsal margin with six spines. The intermediates much longer than the other spines. Body terminates posterior in two long spines, widely separated at their bases, bowed and usually converging towards their free ends. Body length $963 \mu$ and $320 \mu$ in diam.

Sub family: Colurinae

16. Lepadella imbricata Harring, 1966(Pl. 1, Fig.3 $\mathrm{x}$ 100) Battish, 1992,p 81, Fig.66.

Lorica thin, broadly ovate, slightly compressed dorsiventrally, composed of dorsal and ventral plate; foot long with symmetrical toes which is about 2/3 of the length of lorica. Lorica $195 \mu$ and $40 \mu$ in diam.

Phylum:Arthopoda Class: Branchiopoda SubOrder: Cladocera

Family: Daphnidae

17. Daphnia parvula Fordyce1901(Pl.1, Fig.21 $\mathrm{x}$ 60)Edmondson 1966, P.611, Fig.27.24.

Anterior margin of head with broadly rounded crest longest in mid-line. Length $950 \mu$ and breadth in mid region of body $736.45 \mu$. The terminal spine or seta and a small rostrum and a rounded helmet are present.

18. Daphnia longispina Muller 1776 (Pl.2, Fig.17 $\mathrm{x}$ 50) Islam \& Haroon 1975, P.37, Fig.100.

Body length $1864.8 \mu$ and breadth in mid region of body $999 \mu$. The rostrum is very elongated on the front of head. The tail is also with spine and longer than typical Daphnia sp.
19. Moina irrasa Brehm 1937(Pl.1, Fig.19 x 50) Edmondson 1966,P.622,Fig.27.46.

Total length $850 \mu$ and breadth $566 \mu$. Dorsal surface of head hairy. Antennule relatively small and short. Post abdomen with about 11 ciliated pecten, claw pectinate with about 10 teeth in pecten.

20. Moina brachiata Jurine1820 (Pl.1, Fig.17 x 60) Edmondson 1966, P.623, Fig.27.49.

Total body length including brood sac $1658.8 \mu$ and wide brood sac $629.2 \mu$. Post - anal spines 7 to 11 beside bident. Valves faintly reticulate. Antennules of with hooks at tip. Head ordinarily much depressed, so that the vertix often lies almost on level of ventral margin of valves.

21. Ceriodaphnia reticulata Jurine1820 (Pl.1, Fig.23 x 50) Edmondson 1966, P.618, Fig.36.

Total length $1200 \mu$ and breadth $516.15 \mu$. Head obtusely angulated in front of antennules. Valves reticulated, ending in spine or angle. Antennules small with sense hair rear apex. Claws with proximal pecten.

Super Family: Sidoidea

Family: Sididae

22. Diaphanosoma leuchtenbergianum Fischer 1850 (Pl.2, Fig.1 x 60) Edmondson 1966,P.601, Fig.27.8.

Body flattened, covered by transparent valve; Eyes not filling end of head. Reflexed antenna reaching or exceeding posterior margin of valves. Total length $1200 \mu$ and width $572 \mu$.

Family: Macrothricidae

23. Drepanothrix dentata Euren 1861(Pl.2, Fig.2x100) Edmondson 1966,P.627, Fig.27.60.

Total length $858 \mu$ and breadth $268 \mu$. Valves reticulated; dorsal margin arched, crested with conspicuous, short, backward-pointing tooth about middle. Antennules broad, flat, twisted.

Super Family: Polyphemoidea

Family: Polyphemidae

24. Polyphemus pediculus Linne 1761(Pl.1, Fig20 x50) Edmondson 1966, P.599, Fig.27.3.

Body length of the female measured to back of brood sac found $899 \mu$. Brood sac globular. Antennules very small on ventral surface of head. Head large and on it huge movable eyes present. Antennae with 7 setae on each ramus. Legs stout with strong claws and bronchial appendages, fourth pair very small.

Class: Crustacea, Order: **Sub class: Ostracoda Suborder: Podocopa

Family: Cypridae

25. Cyprois occidentalis Sars1926 (Pl. 2, Fig.5 x 60) Bhouyain \&Asmat,1992,p 80, Fig.60.

Body length $1043.9 \mu$ and breadth $715 \mu$. Valves without sculpturing and with hyaline borders at both ends. Second antenna is a biramous structure and expodite rudimentary. Endopidide consists of three segments and 
expodite rudimentary. The basal portion of second antenna bears a long seta.

26. Cypridopsis rhomboidea Furtos1936(Pl. 2, Fig.21 x 150)Edmonson 1966,p.719, Fig. 28.156(a).

Body length $650 \mu$, height $370 \mu$ and width $390 \mu$.Surface of valve pitted, hairy.

27. Cypridopsis yucatanensis Furtos1936(Pl. 1, Fig.22

x 100)Edmonson 1966, p.719, Fig. 28.153(a).

Body length $300 \mu$, height $210 \mu$ and width $250 \mu$.Surface of valves pitted, hairless. Valves smoothly arched dorsally.

28. Limnocythere santi - patrici Brady and Robertson 1869(Pl. 1, Fig.18 x 200) Edmondson 1966, p.725,Fig. 28.174 (a)

Body length $514.8 \mu$, height $300 \mu$ and width $371.8 \mu$. Color dark grayish-white. Valves thin and pellucid. Surface faintly reticulated with scattered hairs at each extremity.

29. Cypricercus obliquus Brady 1866 (Pl. 2, Fig.5 x 200) Edmondson 1966, p.713, Fig. 28.138 (a)

Body length $1200 \mu$, height $590 \mu$ and width $560 \mu$. Color light greenish. End view of valves showing an oblique junction line between the two shells. Terminal claws of furca less than $1 / 2$ the length of ramus.

30. Cypricercus horridus Sars 1926 (Pl. 2, Fig.3 x 100) Edmondson 1966, p.709, Fig. 28.130

Body length $1000 \mu$, height $526 \mu$ and width $666.66 \mu$. Left valves overlaps right. Surface of valves very uneven being everywhere covered with short, stought spikes and densely distributed fine hairs.

Sub class: Copepoda, Order: Eucopepoda

Family : Diaptomadae

31. Neodiaptomus strigilipes Gurney 1907 (Pl.2, Fig.22 x 60) Bhouyain \&Asmat,1992,p 80, Fig.41.

Total length $1251 \mu$ with antennae, female body length $895 \mu$. Breadth of metasoma $429 \mu$ and urosoma $85.8 \mu$. Antennule 25 segmented.

32. Neodiaptomus strigilipes Gurney 1907 (Pl. 2, Fig.9 x 60) Bhouyain \& Asmat,1992,p 80, Fig.42.

Total length $1410 \mu$ with antennae, male body length $898 \mu$. Breadth of metasoma $432 \mu$ and urosoma $57.2 \mu$ broad.

33. Heliodiaptomus contortus Gurney 1907 (Pl. 2, Fig.18 x 60) Bhouyain \& Asmat,1992,p 51, Fig.38.

Total length $692 \mu$ with antennae, body length $487 \mu$. Breadth of metasoma $200 \mu$ and urosoma $71.5 \mu$ broad.

34. Diaptomus pygmaeus Pearse 1906 (Pl. 2, Fig.16 x 100) Edmondson, 1966, p 793, Fig.29.92(a).
Total length $1229 \mu$ with antennae, body length $657.8 \mu$. Breadth of metasoma $143 \mu$ and urosoma $57.2 \mu$.

Family: Cyclopidae

35. Eucyclops agilis Koch, 1838(Pl. 2, Fig.23 x 100) Edmondson, 1966, p 799, Fig.29.106(a).

Total length $790 \mu$ with antennule, body length $504 \mu$. Breadth of metasoma $145.86 \mu$ and urosoma $50.05 \mu$.

36. Cyclops nanus Sars 1863(Pl.2, Fig.10 x 100) Bhouyain \& Asmat,1992, p 59, Fig.44.

Total length $640 \mu$, body length $494.92 \mu$, metasoma $404 \mu$ broad and urosoma $288.86 \mu$ broad. Antennule 13 segmented.

37. Cyclops bicolor Sars 1863(Pl.2, Fig.20 x 100) Edmondson, 1966, p 811, Fig.29.139.

Total length $480 \mu$, body length $307.45 \mu$, metasoma $171.6 \mu$ broad and urosoma $64.35 \mu$ broad. Antennule 10 segmented.

38. Cyclops vernalis Fischer1853(Pl.2, Fig.19 $\mathrm{x}$ 100)Bhouyain and Asmat,1992, p 58,Fig.43.

Total length $680 \mu$, body length $551.3 \mu$, metasoma $143 \mu$ broad and urosoma $57.2 \mu$ broad. Antennule 12 segmented.

39. Cyclops vernalis rubellus Lilljeborg 1901 (Pl.2, Fig.7 x 60) Bhouyain and Asmat, 1992, p 62, Fig.46.

Total length of the female $2145 \mu$, body length $1430 \mu$, metasoma $271.7 \mu$ broad and urosoma $71.5 \mu$ broad. Antennule 12 segmented. Two elliptical egg sac present. Articulation between metasoma and urosoma is distinct.

40. Macrocyclops distinctus Richard 1887 (Pl.2, Fig .13x 60)Battish,1992,p.811,Fig.166.

Total length $400 \mu$, body length $256.97 \mu$, metasoma $112.97 \mu$ broad and urosoma $35.75 \mu$ Antennule 17 segmented.

41. Microcyclops sp.Claus 1893(Pl.2, Fig.4) Bhouyain and Asmat,1992, p 74, Fig.57.

Total length $1287 \mu$, body length $1773.2 \mu$, metasoma $286 \mu$ broad and urosoma $100 \mu$ broad. Antennule 10 12 segmented.

42. Paracyclops fimbriatus poppei Rehberg,1880 (Pl.2, Fig .8x 60) Edmondson,1966 ,p 798, Fig.29.102(a).

Total length $1144 \mu$, body length $786.5 \mu$, metasoma $157.3 \mu$ broad and urosoma $42.9 \mu$ broad. Caudal ramus 3 to 4 times.

43. Mesocyclops leuckarti Claus 1857 (Pl.2, Fig.11 x 60) Bhouyain \& Asmat, 1992, p. 63, Fig.47. 
Total length $1029.6 \mu$, body length $786.5 \mu$, metasoma $200.2 \mu$ broad and urosoma $85.8 \mu$ broad. Antennule with a hyaline plate at last segment with one deep, round notch.

44. Mesocyclops hyalinus Rehberg 1880 (Pl.2, Fig.15 x 100) Bhouyain and Asmat, 1992, p. 66, Fig.50.

Total length $1165.45 \mu$, body length $817.95 \mu$, metasoma $200.2 \mu$ broad and urosoma $57.2 \mu$ broad. Last segment of antennule with unnotched hyaline plate. Distal segment of $5^{\text {th }}$ leg armed with an apical seta and a long terminal or subterminal inner spine or seta.

45. Mesocyclops inversus Kiefer 1936 (Pl.2, Fig.14 x 60) Bhouyain \& Asmat, 1992, p 71, Fig.54.

Total length $1001 \mu$, body length $572 \mu$, breadth of metasoma $224.5 \mu$ and urosoma $85.8 \mu$. Antennule consists of 11 segments.

46. Mesocyclops dybowskii Lande 1890(Pl.2, Fig.12 x 60) Bhouyain \&Asmat, 1992, p 68, Fig.52.

Total length $850 \mu$, body length $715 \mu$, breadth of metasoma $107 \mu$ and urosoma $50.05 \mu$.metasoma 1.7 times longer than urosoma. Last segment of the antennule's without hyaline plate.

Discussion: The zooplankton occupy an intermediatory position between the autotrophs and the carnivores and form an important link in aquatic food webs. The zooplankton population of the concerned habitat was found to be dominated by copepods both in number and diversity followed by rotifers. The abundance of some zooplankton in the aquatic food web is reported to indicate eutrophication(Sprules,1977, Halbach et $a l, 1983)$.Among these members of copepods and rotifers are considered which corroborates with the present findings. Apart this the chemical and redox features of the habitat indicates its eutrophic and presence of high organic load.

\section{Reference}

Ambast, R.S. 1990.Environment \& Pollution (an ecological approach). Student Friends \& Co. India. 230pp.

APHA.1989. Standard methods for the examination of water and waste water.American Public Health association, Washington D.C. USA. 1268pp.
Battiish, S.K. 1992. Freshwater zooplankton of India. Oxford \& IBH Publishing Co. Pvt. Ltd. 233 pp.

Bhouyain, A. M. \& Asmat, G.S.M. 1992. Freshwater zooplankton from Bangladesh. Ghazi Publishers, Dhaka, Bangladesh. 197 pp.

Edmondson, W.T.1966. Fresh water biology. Edmondson (edited), Sc.Eds. John Wiley Sons. Inc. New York, London. 1248 pp.

Gautam,A. 1990. Ecology and pollution of mountain waters (A case study of Bhagirathi river).Ashish Pub.House,New Delhi.144pp.

Halbach,U., Siebart,M., Wastmayear,M. \& Wissel,C. 1983. Population ecology of rotifers as a bioassay tool for ecotoreicological testes in aquatic environment. Ecotoreical. Environ.Safety. 7: 484-513.

Islam, A.K.M.N. \& Haroon, A.K.Y.1975. Limnological studies of the river Buriganga. Biological aspects. Dacca Univ.Stud. B 23(1): 25-44.

Michael, R. G., 1968. Studies on the zooplankton of a tropical freshwater fish pond and their role in fish culture. $J$. Madurai Univ.Suppl. 33: 144-160.

Mishra, S. R. \& Saksena, D. N.1992. Aquatic Ecology. Asish Pub. House, Delhi. 691pp.

Needham, J. G. and Needham, P.R. 1966. A guide to the study of fresh water biology ( $5^{\text {th }}$ eds.). Holden Day Inc. San Francisco, Calif., USA. 104 pp.

Sharup, R., Mishra, N \& Jauhari, V.P. 1992. Encyclopedia of ecology, environmental air and water analysis. 17: 40138.

Sprules,W.G. 1977. Crustacean zooplankton communites as indicator of limnological conditions. An approach using principal component analysis. J.Fish.Res.Bd.Can., 34: 962-975.

Transeau, E.N. 1951.Periodicity of Fresh water algae. Amer.J.Bot.3:121-123.

Welch, P.S. 1948. Limnological methods. McGraw Hill Book Co. NewYork.377pp.

Manuscript received on 25.06.2007, accepted on09.042008 